\title{
The Presence of Chronic Kidney Disease in Relation to Age and Duration of Diabetes Mellitus
}

\author{
IO NELA MIHAELA VLADU1\#, TIBERIU STEFANITA TENEA COJAN²*, ALIN DEMETRIAN", OANA MARIANA CRISTEA*, \\ CRISTINA GABRIELA ENE ${ }^{5}$, DIANA CLENCIU ${ }^{6}$ \\ ${ }^{1}$ University of Medicine and Pharmacy of Craiova, Department of Metabolism and Nutrition Diseases, Filantropia Clinical \\ Hospital of Craiova, 1 Filantropiei Str., 200143, Craiova, Romania \\ ¿University of Medicine and Pharmacy of Craiova, Department of Surgery, CFR Hospital of Craiova, Stirbei-Voda Str., 200374,Craiova, \\ Romania \\ 3University of Medicine and Pharmacy of Craiova, Department of Thoracic Surgery, County Hospital Craiova, 2-4 Petru Rares \\ Str.Craiova, 200349 Romania \\ ¿University of Medicine and Pharmacy of Craiova, Department of Microbiology, County Hospital Craiova, 2-4 Petru Rares \\ Str.Craiova, 200349 Romania \\ 5University of Medicine and Pharmacy of Craiova, Pharmacology Department, County Hospital of Craiova, 2-4 Petru Rares \\ Str.,200349, Craiova, Romania \\ University of Medicine and Pharmacy of Craiova, Department of Metabolism and Nutrition Diseases, Filantropia Clinical \\ Hospital of Craiova, 1 Filantropiei Str., 200143, Craiova, Romania
}

\begin{abstract}
Chronic kidney disease (CKD) affects about 10-13\% of the general population with a small proportion in the terminal renal disease stage requiring renal replacement therapy or renal transplantation. CKD is the new cause of mortality in the US. CKD's prevalence increases with age. Diabetes mellitus is responsible for $50 \%$ of cases of chronic kidney disease being the most common cause.
\end{abstract}

Keywords: Type 1 diabetes mellitus, chronic kidney disease

Chronic kidney disease (CKD) affects about $10-13 \%$ of the general population with a small proportion in the terminal renal disease stage requiring renal replacement therapy or renal transplantation. CKD is the new cause of mortality in the US. CKD's prevalence increases with age. Diabetes mellitus is responsible for $50 \%$ of cases of chronic kidney disease being the most common cause [1]. Diabetic CKD is the most common cause of chronic renal failure involving renal replacement therapy worldwide, especially in the type 2 diabetes patients [2-4]. Diabetes mellitus (DM) is responsible for $30-40 \%$ of the causes of end-stage renal disease in the United States [5-11]. In the past 30 years, the rate of type 1 DM requiring renal replacement therapy declined considerably due to improved treatment strategies for DM and artherial hypertension [12-16].

Diabetes mellitus (DM) is a chronic disease which can evolve towards devastating micro and macro-vascular complications. DM is the most frequent cause of chronic kidney disease (CKD). The diabetic chronic kidney disease (CKD) is a clinical syndrome characterized by persistent albuminuria (albumin/creatinine ratio in the spontaneous urine $\geq 30 \mathrm{mg} / \mathrm{g}$ ) and $/$ or a sustained decline of the estimated glomerular filtration rate (eGFR) below $60 \mathrm{~mL} / \mathrm{min} / 1.72 \mathrm{~m}^{2}$ [17-20]. If at least one of these values is still maintained within these abnormal limits after 3 months from the first measurement, the diagnosis of diabetic CKD may be established [21-26].

Older age and a long evolution of DM are factors known and shown in numerous studies to be associated with the development and progression of chronic complications in diabetes [27-37]

\section{Experimental part}

The aim of the study

The aim of this study was to assess the presence of chronic kidney disease in relation to age and duration of type 1 and type 2 diabetes mellitus.
Material and method

The study type is epidemiological, transversal, noninterventional, with unselected patients. It was performed by analyzing 600 subjects divided into three groups, as follows: Lot 1 includes 200 patients with type 1 diabetes, Lot 2 includes 200 patients with type 2 diabetes and lot 3 (control) consisting of randomly recruited 200 individuals without diabetes.

We recorded demographic data (age, gender), anthropometric data (weight, height, body mass index, waist circumference, hip circumference), personal physiological history (menarhas, births, abortions, fetal macrosomia, menopause), personal pathological history (DM, hypertension, dyslipidaemia, stroke, myocardial infarction, obesity, autoimmune diseases, microvascular complications of DM (retinopathy, diabetic neuropathy, diabetic nephropathy). Patients were questioned about smoking status.

The following laboratory blood counts were performed: serum creatinine, total cholesterol, HDLcholesterol, triglycerides, uric acid, serum hemoglobin; LDL-cholesterol was calculated with the Friedwald formula.

The estimated glomerular filtration rate was performed by the MDRD 4 method avalable online (http:// www.mdcalc.com/mdrd-gfr-equation/) and the CKD prognosis assessment was performed using the KDIGO 2012 risk chart (35).

Recorded data were analyzed using the SPSS software 17.00 (IBM Corporation, Armonk, NY, USA). The methods used were: t-test, Mann-Whitney test, Chisquare test, simple binary logistic regression, multiparametric logistic regression and multiparametric logistic regression with stepwise covariate selection.

\section{Results and discussions}

We conducted a study on 600 subjects ( 289 women and 311 men) divided into 3 batches. 
Patients enrolled in group 1 were 84 (42\%) women, 116 (58\%) men, in the group 2,101 (50\%) women and $99(50 \%)$ men, and in the control group 104 (52\%) women 96 (48\%) men (fig. 1).

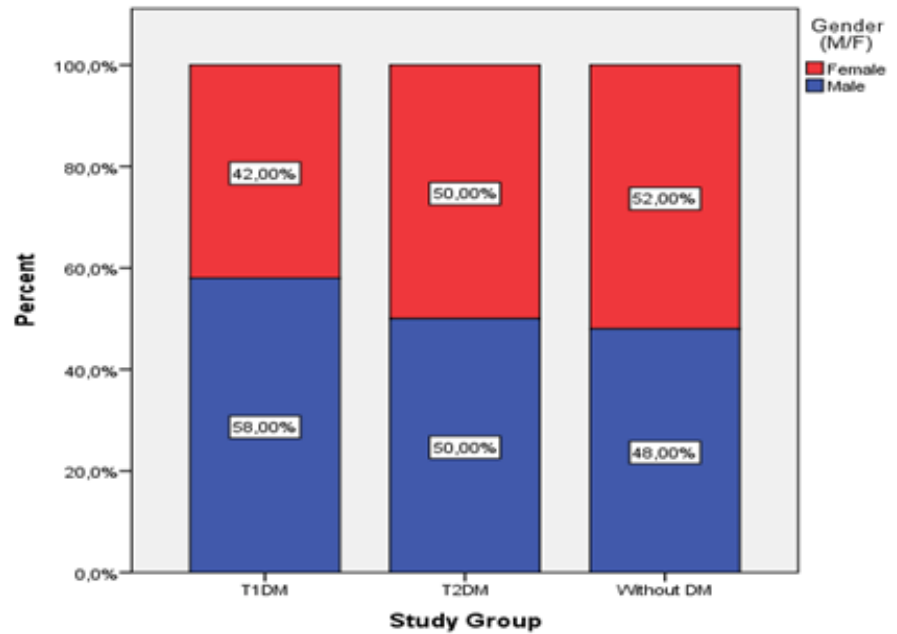

Fig. 1. The repartition of the three studied groups according to the gender of patients

We evaluated the presence of kidney disease in each of the three lots. Based on the KDIGO 2013 criteria, we identified patients diagnosed with CKD with the following variants:

-patients with an estimated glomerular filtration rate (eGFR) < 60mL / $\min / 1.73 \mathrm{mp}$ and absent albuminuria

-patients with an eGFR $<60 \mathrm{~mL} / \mathrm{min} / 1.73 \mathrm{mp}$ and presentalbuminuria

-patients with an eGFR $>60 \mathrm{~mL} / \mathrm{min} / 1.73 \mathrm{mp}$ and presentalbuminuria

In group 1, diabetic CKD in patients with type 1DM, was found to be $44.5 \%$; in group 2, in patients with type $2 \mathrm{DM}$, diabetic CKD was found to be $53.5 \%$ and in the control group $8 \%$ (fig. 2, yable 1).
We calculated the coefficient of contingency Phi and Cramer 's V, obtaining the value of 0.412 . There is a statistically significant difference between the three groups ( $p<0.0001$ ) with respect to the presence of CKD, the highest percentage being seen in patients with type $2 \mathrm{DM}$, followed by patients with type $1 \mathrm{DM}$ and a small percentage in the control group.

Depending on the estimated glomerular filtration rate, we have staged CKD in the 5 stages. Figures 3-5 highlight the presence of CKD for each group.

The patients analyzed were in varying degrees of CKD after the KDIGO classification in 2012. Thus, in group 1, most patients were in stage 2 of CKD (53.93\%), followed by stage $1(25.85 \%)$, Stage 3a (11.23\%), Stage 3b and G4 (3.37\%), Stage 5 representing $2.25 \%$ (fig. 3).

In group 2, most patients were still in stage 2 of CKD (42.99\%), followed by Stage 3a (26.16\%), then Stage 1 $(20.57 \%)$, Stage $3 b(7.48 \%)$, Stage $40.94 \%$ and $1.86 \%$ in Stage 5 (fig. 4).

In the control group, half of patients with $B C R$ were in stage $3 a(50 \%)$, followed by stage $2(18.75 \%), 3 b$ and 4 each in $12.5 \%$, respectively stage $5(6,25 \%$ ) (fig. 5 ).

The age of patients with type 1 diabetes who have chronic kidney disease (CKD) was lower versus the age of patients with type 2 diabetes and CKD, but comparable between patients with type 2 diabetes and those without diabetes (control). This was proven by the Mann-Whitney $U$ and Wilcoxon W statistical tests, showing significant differences between age of patients with type 2 diabetes with CKD and the age of patients with TIDM with CKD ( $p$ $<0.001$ ) between patients with diabetes type 1 with CKD those without diabetes (control) with CKD $(p<0.001)$, but not significant between type 2 diabetes and CKD control group ( $p=0.910$ ) (fig. 6 , table 2).

The average age of developing CKD in type 1 diabetes was around 43.55 years; in T2DM the average age was

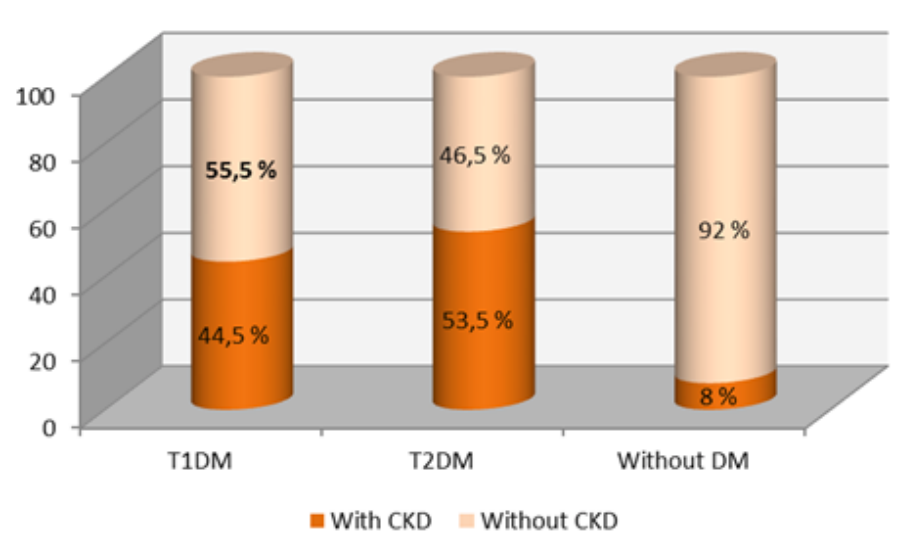

Fig. 2. The presence of diabetic CKD in the three groups (subjects with type $1 \mathrm{DM}$, type $2 \mathrm{DM}$ and control group)

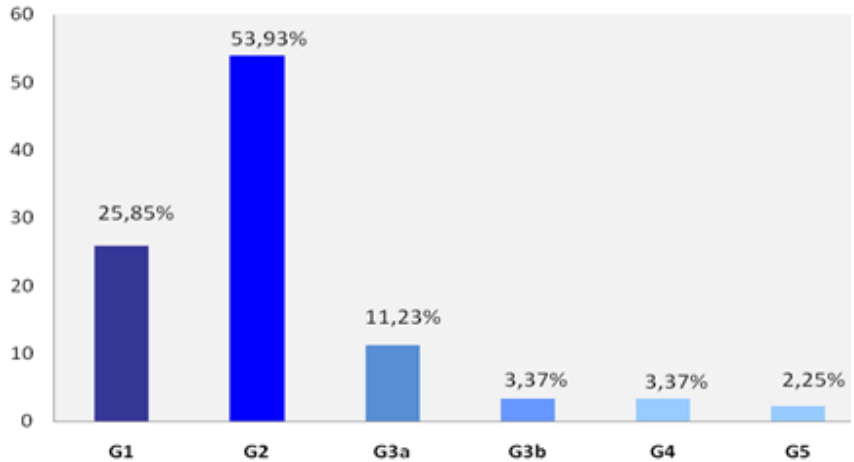

Fig. 3. Stage distribution of diabetic CKD in patients with type 1 DM

\begin{tabular}{|c|c|c|c|}
\hline \multirow{2}{*}{ GROUP } & \multicolumn{2}{|c|}{ Diabetic CKD } & \multirow{2}{*}{ TOTAL } \\
\cline { 2 - 3 } & NO & YES & \\
\hline \multirow{2}{*}{ GROUP 1 = TIDM } & 111 & 89 & 200 \\
\hline \multirow{2}{*}{ GROUP 2 = T2DM } & $55.5 \%$ & $44.5 \%$ & $100.0 \%$ \\
\cline { 2 - 4 } & 93 & 107 & 200 \\
\cline { 2 - 4 } GROUP3 = Without DM & $46.5 \%$ & $53.5 \%$ & $100.0 \%$ \\
\cline { 2 - 4 } & 184 & 16 & 200 \\
\hline \multirow{2}{*}{ TOTAL } & $32.0 \%$ & $8.0 \%$ & $100.0 \%$ \\
\cline { 2 - 3 } & $64.7 \%$ & 212 & 600 \\
\hline
\end{tabular}

Table 1

THE PRESENCE OF DIABETIC CKD IN THE THREE GROUPS 


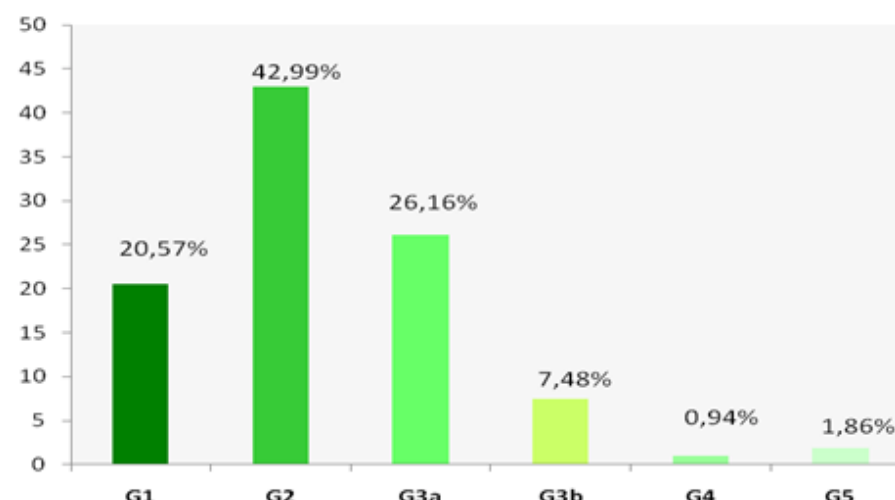

Fig. 4. Stage distribution of diabetic CKD in patients with type 2 DM

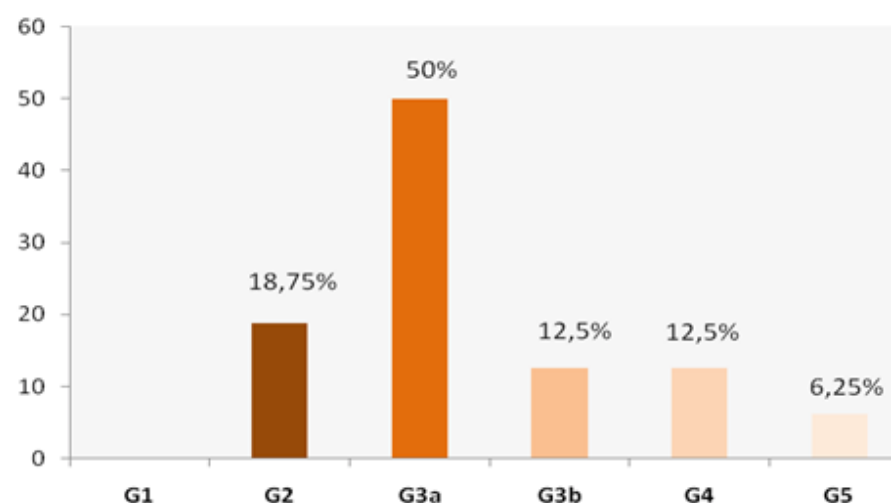

Fig. 5. Stage distribution of diabetic CKD in control group

64.93 years and 63.94 years in the control group. The Kruskal Wallis statistical test showed statistically significant differences between type 1 and type 2 diabetes and between T1DM and the control group ( $p<0.001)$, but not significant between T2DM and the control group (table 3).

The age of patients at diagnosis of diabetes with CKD was statistically significant $(p<0.001)$ lower in patients with type 1 diabetes than in those with type 2 diabetes. Applying the statistical Mann-Whitney U testand Wilcoxon W we found significant differences between age

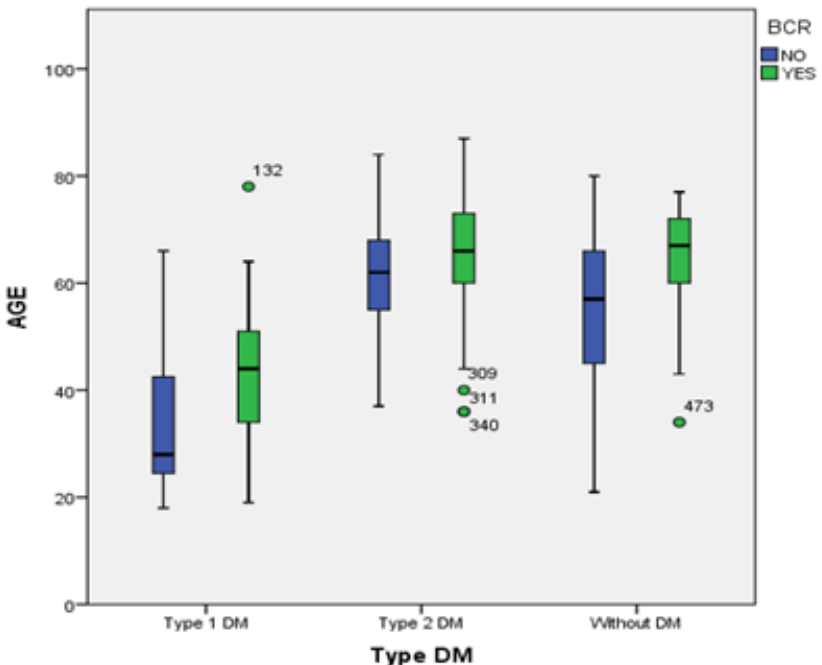

Fig. 6. Correlation between age and the presence of chronic kidney disease in the three groups

Table 2

DIABETIC CKD IN RELATION TO THE AGE OF PATIENTS WITH DM

\begin{tabular}{|l|c|c|}
\hline & TIDM & T2DM \\
\hline P-value & $<0.0001$ & 0.012 \\
\hline Odds ratio & 1.083 & 1.039 \\
\hline $95 \% \mathrm{Cl}$ & $1.054-1.113$ & $1.008-1.070$ \\
\hline
\end{tabular}

diagnosing diabetes in patients with type 1 diabetes compared with CKD aged patients with type 2 diabetes with CKD ( $p<0.001)$ (fig. 7).

The average duration of development of type 1 diabetes associated with CKD stood around 20 years, being statistically significant $(p<0.001)$ higher compared to the duration of 8.5 years of development in patients with type 2 diabetes associated with CKD (fig. 8, table 4). The Kruskal Wallis statistical testapplied showed statistically significant differences between type 1 and type 2 diabetes mellitus $(p<0.001)$.

\begin{tabular}{|l|l|c|c|c|c|c|}
\hline \multicolumn{2}{|l|}{} & N & Media & $\begin{array}{c}\text { Std. } \\
\text { Deviation }\end{array}$ & Minim & Maxim \\
\hline \multirow{3}{*}{ AGE } & $\begin{array}{l}\text { Control Group } \\
\text { (without DM) }\end{array}$ & 16 & 63.94 & 11.953 & 34 & 77 \\
& TlDM & 89 & 43.55 & 10.744 & 19 & 78 \\
\cline { 2 - 8 } & T2DM & 107 & 64.93 & 9.921 & 36 & 87 \\
\cline { 2 - 8 } & Total & 212 & 55.88 & 14.774 & 19 & 87 \\
\hline
\end{tabular}

Table 3

THE MEAN AGE OF CKD IN THE SUBJECTS OF THE 3 GROUPS

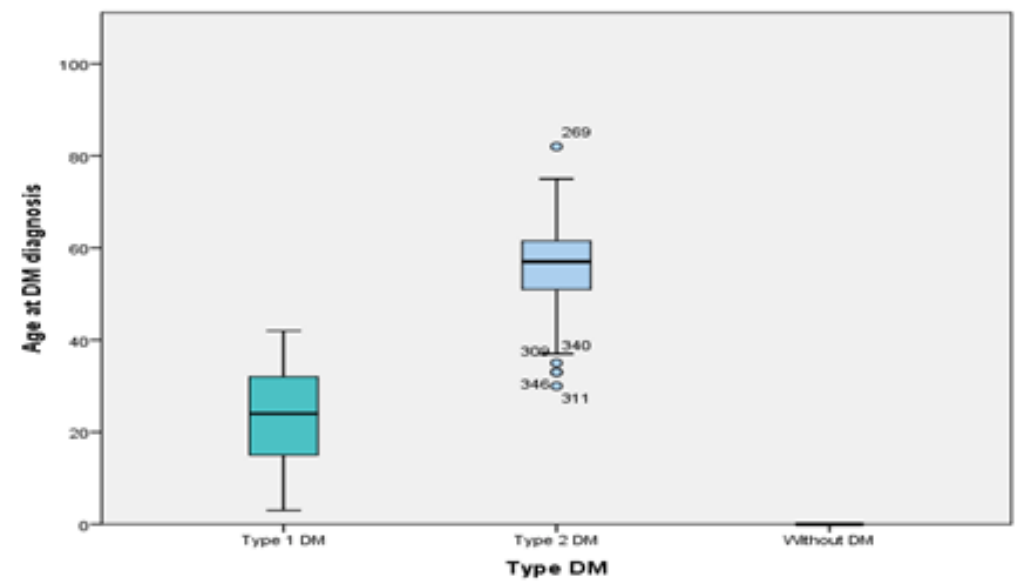

Fig. 7. The correlation between age at diagnosis of DM and the presence of CKD in the three groups 


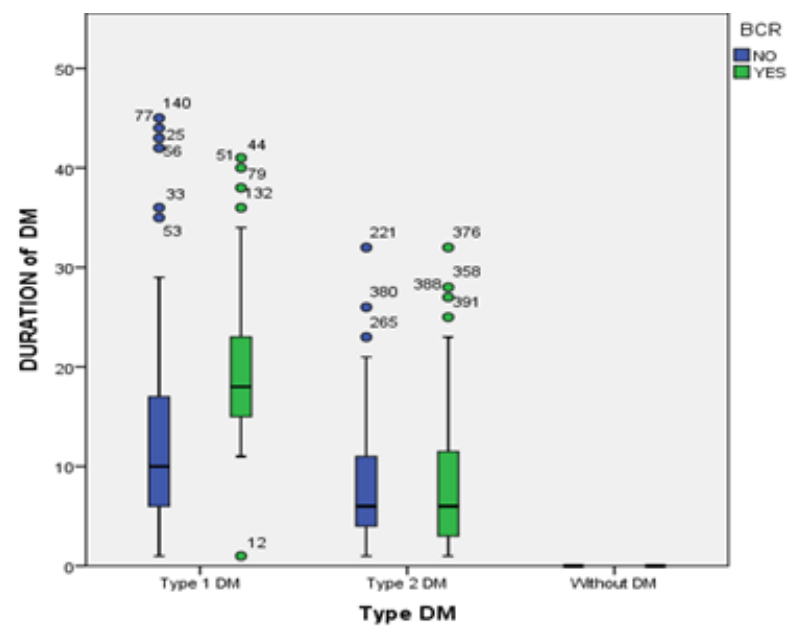

Fig. 8. The correlation between duration of DM and the presence of CKD in the three groups

\begin{tabular}{|l|l|c|c|c|c|c|}
\hline \multicolumn{2}{|l|}{} & N & Media & $\begin{array}{c}\text { Std. } \\
\text { Deviation }\end{array}$ & Minim & Maxim \\
\hline \multirow{4}{*}{$\begin{array}{l}\text { Duration } \\
\text { of DM }\end{array}$} & $\begin{array}{l}\text { Control Group } \\
\text { (without DM) }\end{array}$ & 16 & .00 & .000 & 0 & 0 \\
\cline { 2 - 8 } & TlDM & 89 & 20.01 & 6.595 & 11 & 41 \\
\cline { 2 - 8 } & T2DM & 107 & 8.50 & 6.912 & 1 & 32 \\
\cline { 2 - 8 } & Total & 212 & 12.69 & 9.265 & 0 & 41 \\
\hline
\end{tabular}

Table 4

AVERAGE AGE OF CKD IN THE SUBJECTS OF THE 3 GROUPS

\section{Conclusions}

Diabetic CKD prevalence increases with age and duration of diabetes. Age of occurrence of CKD is lower in patients with type 1 diabetes compared to those with type 2 and the general population. CKD incidence and prevalence increases with age. Old age seems to be a negative predictor for the occurrence of end stage of CKD.

\section{References}

1. PERNEGER TV, BRANCATI FL, WHELTON PK, KLAG MJ. Endstage renal disease attributable to diabetes mellitus. Ann Intern Med. 1994;121912- 918

2. BRENNER BM, MACKENZIE HS. Nephron mass as a risk factor for progression of renal disease. Kidney Int. 1997;52(suppl 63)124127

3.STREBA LAM, CARSTEA D, MITRUT P, VERE CC, DRAGOMIR N, STREBA CT. Nonalcoholic fatty liver disease and metabolic syndrome: a concise review. Rom J Morphol Embryol 2008;49(1):13-20.

4.VREJU FA, CIUREA ME, POPA D, POPA F, PARVANESCU CD, CHISALAU BA, BARBULESCU AL, PARVANESCU V, ROSU A, CIUREA PL. Ultrasonography in the diagnosis and management of non inflammatory conditions of the hand and wrist. Med Ultrason, 2016, 18(1):90-95.

5.CALBOREAN, V., GHEORMAN, V., ISTRATOAIE, O., MUSTAFA, R.E.,COJ OCARU, P.A., ALEXANDRU, D.O., GALCEAVA, O., MITA, A.,MISCOCl, S.A., AL NAMAT, R., GHEONEA,D.I. QT interval analysis in patients with chronic liver disease, Rev. Chim. (Bucharest), 69, no. 5, 2018, p.1134-1138.

6. CALBOREAN, V., CIOBANU, D., MIREA, S.C., GALCEAVA, O.,GHEORMAN, V., PADUREANU, V., FORTOFOIU, C.M., FORTOFOIU,M., MITA, A., DINESCU, S.N., MISCOCI, S.A., DINESCU, V.C. Benefit of Cardiac Resynchronization Therapy in Patients with Heart Failure. Rev. Chim. (Bucharest), 69, no. 9, 2018, p.2461-2464. 7. CALBOREAN, V., MISCOCI, S. A., ISTRATOAIE, O., GALCEAVA , 0., ALEXANDRU, D.O., GUTA, M.M., GHEORMAN, V., PADUREANU, V., FORTOFOIU, C.M., DIJMARESCU, A.L., GHEONEA, D.I., Correlation Between Liver Cirrhosis and Risk of Cardiac Arrhythmias, Rev Chim(Bucharest), 69, no. 6, 2018, p. 1527-1532.
8.GHEORMAN,V., MILITARU, F., CALBOREAN,V., GHEORMAN, L.M.,CHIRITA, A.L., MITA, A., GALCEAVA, O., GHEORMAN, V., STANCA, D.,UDRISTOIU, I., Clinical and biochemical consideration regarding stress and arrhytmic risk in patients with chronic viral liver diseases, Rev Chim. (Bucharest), 69, no. 4, 2018, p.881-885.

9.PUIU,I., ALBU,C.V., TARTEA,E.A., CALBOREAN,V., GHEORMAN,V., DINESCU,S.N., VASILE,R.C., DINESCU,V.C., BICA, E.C., ROMANESCU, F.M., TUDORASCU,D.R. Relationships Between Glial Enteric Cells, Beta-cell Signaling and Tumor Proliferative Activity in Patients with Colorectal Neoplasia, Rev Chim (Bucharest), 69, no. 10, 2018, p. 2744-2748.

10.TRASCA, S.P., FLORESCU, C., DINESCU, V.C.,PUIU, I., DINESCU, S.N., TUDORASCU, D.R., BICA, C., VASILE, R.C., ROMANESCU, F.M., BUNESCU, M.G., CIOATERA, N., GOANTA, E.V. Rev Chim (Bucharest), 69, no.12, 2018, p.3600-3604.

11.CALBOREAN, V., GHEORMAN, V.,CONSTANTIN, C. ISTRATOAIE, 0. Venous Thromboembolism Secondary to Adult-Onset Still's Disease: a Case Report . J ournal of Cardiovascular Emergencies, 2018, 4, nr.2, p. 101-105.

12. WHELTON PK, KLAG MJ. Hypertension as a risk factor for renal disease: review of clinical and epidemiological evidence. Hypertension. May1989;13(5 suppl)।19- I27

13.GHEORMAN,V.,CHIRITA,A.L.,DUMITRESCU,E.M.,ROGOVEANU,I., ISTRATOAIE, O.,GHEORMAN,V., PANA,R.C. Particularities of associating viral hepatitis with pregnancy and mental disorders, Rom J Morphol Embryol 2016, 57(1): 45-50.

14. CALBOREAN,V., GHEORMAN,V., AL NAMAT, R., CAZACU,I. M., VARJU,P., GEDE, N., STREBA,T.C., VERE, C.C., GHEONEA,D.I., GHEORMAN, V., LUNGULESCU, C., LUNGULESCU, C.,V. The Association Between Stress Level and Laboratory Parameters, Sex, Age and Stage Disease in Patients with Digestive and Bronchopulmonary Neoplasms, Rev. Chim. (Bucharest), 68, no. 12, 2017, p.3010-3014.

15.BALEANU, V.D., CONSTANTIN, D.V., PASCAL, A., ALEXANDRU, D.O., BOBIC, S., SOCEA, B., MANDA, A.L., DAVITOIU, D., DIJ MARESCU, A.L.,GEORGESCU, I., MIREA, C.S. Use of Synthetic Protetic Materials in Surgical Abdominal Defects Analysis of the 
Advantages and Lack of the Liechtenstein Method. Rev. Chim (Bucharest), 69, no. 7, 2018, p. 1740-1743.

16.NOVAC, M.V., NICULESCU, M., MANOLEA, M.M., DIJ MARESCU, A.L., ILIESCU, D.G., NOVAC,M.B., ROTARU,L.T, STOENESCU, M.F., TABACU, M.C.,TUDORACHE, S., BUSUIOC, C.J ., GHEONEA, I.A. Placental findings in pregnancies complicated with iugrhistopathological and immunohistochemical analysis.Rom J Morphol Embryol , 2018, vol 59, p. 715-720.

17.STOENESCU,V.E., NICULESCU,M., NOVAC,L., MANOLEA,M.M., TOMESCU, P.I., DIJ MARESCU, A.L., NOVAC, M.B., TUDORACHE, S., ILIESCU, D.G. Immunohistochemical reaction of the glandular epithelium in endometrial hyperplasia compared to endometrial carcinoma. Rom J Morphol Embryol , 2017, vol 58, p. 791-800.

18.SIMINEL,M.A., GHEONEA,C., STANESCU,M.R., COMANESCU, A.C., DIJ MARESCU, A.L., NEAMTU, S.D., COTOI, B.V., NEDELCUTA, R.M., NICULESCU, E.C. Velamentous insertion of the umbilical cord vessels with vasa praevia - a case report .Rom J Morphol Embryol, 2015, vol 56, 301-308.

19.BUICU, G.E., GRECU, M.G., SALCUDEAN, A., GRECU, I.G., MARINESCU, C., NIRESTEAN, A., TURLIUC, S., HADAREANU, V., UDRISTOIU, I. Evaluation of elder physical abuse. EUROPEAN PSYCHIATRY, 41, 2017, p S583-S584.

20.CHIMORGIACHIS,A.,CONSTANTIN,M.D.G.,UDRISTOIU,T., PIRLOG, M.C.,UDRISOIU,I. Weight gain in patients with schizophrenia and atypical antipsychotic treatment - neurobiological correlations. JOURNAL OF NEURAL TRANSMISSION, 114, issue 7, 2007, p. CXXCXX.

21. K/DOQI clinical practice guidelines for chronic kidney disease: evaluation, classification, and stratification. Am J Kidney Dis 2002; 39 (2 Suppl. 1): S1-266.

22. *** KDIGO 2012. Clinical Practice Guideline for the Evaluation and Management of Chronic Kidney Disease. 2013; 3 (1): 5-8. Available at http://www.kidney-international.org

23.RADU,L., CARSOTE, M.,GHEORGHISAN GALATEANU, A.A., PREDA, S.A., CALBOREAN, V., STANESCU, R., GHEORMAN, V., ALBULESCU, D.M. .Blood Parathyrin and Mineral Metabolism Dynamics - A clinical analyze, Rev.Chim.(Bucharest) 69, no. 10, 2018 , p. 2754-2758

24. RADU, L., CARSOTE, M., PREDESCU, A.M., TENEA-COJAN, T.ST., SOCEA, B.,V.D. BALEANU, V.D., POPESCU, M., IONOVICI, N., ALBULESCU, .D.M. Biochemical parameters in patients using teriparatide. Rev. Chim (Bucharest) ,69, no. 12, 2018, p.3483-3485.

25.VLADU, I.M., RADU, L., GIRGAVU, S.R., BALEANU, V., CLENCIU, D., ENE, C.G., SOCEA, B., MAZEN, E., CRISTEA, O.M., MOTA,M., TENEA COJAN, T.S.- An Easy Way to Detect Cardiovascular Risk, Rev. Chim.(Bucharest) 69, no. 11, 2018, p. 4229-4232

26. SOCEA, B.,RADU, L., CLENCIU, D., TENEA COJAN, T.S., BALEANU, V., ENE, C.G., GIRGAVU,S.R., VLADU,I.M. The Utility of Visceral
Adiposity Index in Prediction of Metabolic Syndrome and Hypercholesterolemia Rev.Chim.(Bucharest) 69, no. 11, 2018, p. 3112-3114

27. VLADU,M., CLENCIU,D., EFREM, I.C., FOROFOIU,M., AMZOLINI,A., MICU, S.T., MOPA, M., FOROFOIU, M.C. Insulin Resistance and Chronic Kidney Disease in Patients with Type 1 Diabetes Mellitus. Journal of Nutrition and Metabolism, vol. 2017, Article ID 6425359, 5 pages, 2017. doi:10.1155/2017/6425359.

28.ENE, C.G., ROSU, A., GHEORMAN, V., CALBOREAN, V., TENEA COJAN, T.S., ROGOVEANU, O. C., VLADU, M. I., RADU, L. Incidence of Osteoporosis and the Risk of Fracture in Patients with Rheumatoid Arthritis Undergoing Corticosteroid Treatment, Rev. Chim. (Bucharest), 69, no.7, 2018, p.1851-1854

29.TENEA COJAN T.S. , VIDRIGHIN C.D. , CIOBANU M., ET.ALL Breast conserving surgery in breast cancer, Chirurgia , Vol 107, Issue 5 (sept- oct 2012) , pg 616-625.

30.VLADU, I.M., RADU, L., GIRGAVU, S.R., TENEA COJAN, T. ST., ENE, C.G., CALBOREAN, V. GHEORMAN, V., CLENCIU, D. .Alteration of Glucidic Metabolism in Relation with Visceral Adiposity Index. Rev.Chim.(Bucharest) 69, no.9,2018, p. 2479-2481.

31.VASILE I., MIREA C., VILCEA I.D. ET ALL Esophago-digestive anastomosis dehiscence, Chirurgia, vol 104, No. 3 (May-lun 2009), pg 281-286

32.CORICI O.A, TANASIE C.A., ALEXANDRU D.O., FLORESCU, M.C. COMANESCU M.V., KAMAL C , TENEA-COJAN T.ST., IANCAU M., DINESCU S.N. A morpho-functional study using PEP/LVET ratio and global longitudinal strain in patients with dilated cardiomyopathy Rom J Morphol Embryol 2018, 59(1):93-103

33.FORTOFOIU, M., FORTOFOIU, M.C., COMANESCU, V., DOBRINESCU, A.C., PADUREANU, V., VERE, C.C., STREBA, C.T., CIUREA,P.L., Hepatocellular carcinoma and metabolic diseaseshistological perspectives from a series of 14 cases Rom. J. Morphol. Embryol., 56, 4, 2015, p. 1461-1465

34.MARINAS, A.E., CIUREA, P., MARGARITESCU, CL., COTOI, O.S. Expression of Epidermal Growth Factor (EGF) and its receptors (EGFR1 and EGFR2) in chronic bronchitis, Rom. J. Morphol. Embryol., Vol.53, Issue 4, pg.957-966

35.CALBOREAN,V.,GHEORMAN, V., DINESCU, S.N., STANCA, D., GALCEAVA, O., FORTOFOIU,M., MITA, A., MIHAILOVICI, A.R., MISCOCl, S.A., BALEANU,V.D., DINESCU, V.C. Arrhythmia risk in patients with chronic hepatic disease. Rev Chim (Bucharest), 69, no. 11, 2018, p. 4237-4240.

36. MIHAILOVICI, A.R., PADUREANU, V., ALBU, C.V., DINESCU, V.C., PIRLOG, M.C., DINESCU, S.N., MALIN, R.D.,CALBOREAN, V. Myocardial noncompaction. Rev Chim. (Bucharest), 69, no. 8, 2018, p.2209-2212. 37. LEVEY AS, STEVENS LA, SCHMID CH ET AL. A new equation to estimate glomerular filtration rate. Ann Intern Med 150: 604-612, 2009. 